\title{
How to Be a Pilgrim: Guidebooks on the Norwegian St. Olav Ways and the Heritagization of Religion
}

\author{
DirkJohannsen \\ Department of Culture Studies and Oriental Languages, University of Oslo, \\ Oslo, Norway \\ dirk.johannsen@ikos.uio.no \\ Ane Ohrvik \\ Department of Culture Studies and Oriental Languages, University of Oslo, \\ Oslo, Norway \\ ane.ohrvik@ikos.uio.no
}

\begin{abstract}
The Norwegian St. Olav Ways are currently the largest Northern European project reinstitutionalizing pilgrimage as cultural heritage, providing a new framework for vernacular religious practices to a wide audience. In this article we approach the current pilgrimage revival in Northern Europe as part of a trend toward a heritagization of religion that allows new religious self-understandings to emerge. We analyze pilgrim guidebooks to the St. Olav Ways with regard to their narrative scripts, detailing how they can create expectations, inform the pilgrims' conduct, and direct their attention toward a history that translates into a heritage. Based on a corpus of published pilgrim journals and diaries, we argue that the guidebooks instruct a process of interpretive drift, which influence the pilgrims toward embracing and embodying a new role within the religious field. The guidebooks invite the pilgrims to take on the role of heirs to a medieval European tradition.
\end{abstract}

\section{Keywords}

pilgrimage - heritagization of religion - pilgrim guidebooks - immersion - interpretive drift 
In recent decades, cultural heritage has become a core concept for administering the past on a global scale (Blake 2000; Meskell 2015). Places, objects, stories, customs, practices, and even beliefs and values are deemed to be inherited, and therefore to fall under the shared responsibility of their heirs: diverse and sometimes contested local, ethnic, national, European, or global communities (Harrison 2013; Eriksen 2014). Translating history into heritage changes the perception of the past (Tolia-Kelly, Waterton, and Watson 2017). Processes of heritagization trigger complex dynamics, not least within the religious field (Meyer and de Witte 2013; Salemink 2016; Rots and Teeuwen 2020). With UNESCO's category of "heritage of religious interest," applied from 2010 onwards, religious traditions gain new and broader ownership, practices acquire new meaning, and long-abandoned sites or "sacred landscapes" become "religious property," bound to a usage that accounts for this status. ${ }^{1}$ The European pilgrimage revival of recent decades is another striking example of the dynamics of this ongoing "heritagization of religion" (Bowman and Sepp 2019). Pilgrimage is increasingly marketed and practiced as a way to engage with a religious past in the format of an "immersive' heritage encounter" (Kidd 2018). With refurbished pilgrim routes emerging in European countries where pilgrimage was long abandoned and had become disconnected from confessional beliefs, we now witness an explorative development of new religious formats, expressions, and identities on the move.

The St. Olav Ways to Nidaros Cathedral in Trondheim, Norway, are currently the most extensive governmental project reintroducing pilgrimage to the Northern European countries. With a route network of now more than $3400 \mathrm{ki}-$ lometers, a growing infrastructure of pilgrim hostels and pilgrim centers, and a professional international marketing campaign, they attract a broad variety of visitors. The Norwegian Pilgrim Center (NPS), situated within the Ministry of Culture department for monument preservation (Nidaros Cathedral's Restoration Workshop [NDR]), administers the pilgrim paths to Trondheim as a part of a national pilgrimage initiative. ${ }^{2}$ With a focus on the sustainable development of heritage tourism and the promotion of the local economy, the St. Olav Ways, as a designated Cultural Route of the Council of Europe, are

1 See UnESCo, n.d. For more examples of processes of heritagization of religion and a discussion of the notion of pilgrimage, see the introduction to this special issue.

2 See St. Olav Ways, n.d.a. 
officially promoted as European cultural heritage. ${ }^{3}$ Catering to an audience often unfamiliar with traditional pilgrimage, the St. Olav Ways have become a stage where new and diverse pilgrim identities are developed and rehearsed.

The refurbished St. Olav Ways bear all the hallmarks of a "Caminoized" pilgrimage, such as a focus on long-distance walking, "branded" waymarkers along a historical route, a pilgrim passport, and a certificate of completion (Bowman and Sepp 2019). However, the far less frequented and remote routes, the physically much more challenging topography, the harsher climate, and the historic narrative of a Viking king that unified the country by becoming a martyr make walking the St. Olav Ways a very different experience from walking the Camino de Santiago. With pilgrimage traditions and the veneration of saints long abandoned in Norway, many travelers feel that simply following a waymarked trail does not yet constitute a pilgrimage. "Am I a pilgrim?" is a question emerging in many of the contemporary pilgrim accounts analyzed below (e.g., Pichler 2018: 34). The tension between historical ideas of pilgrimage and their contemporary format is a dominant topic in the St. Olav Ways' official promotional material, and much of the media coverage. The medium with the most significant impact on negotiating "how to be a pilgrim," however, is the independently published pilgrim guidebooks.

In this article, we approach pilgrim guidebooks as a source valuable for revealing the social experience of heritage (Harrison 2013) as a crucial dynamic in processes of the heritagization of religion. Pilgrim guidebooks serve a wider purpose than just pointing the pilgrim in the right geographical direction; covering every aspect of the journey, they inform day-to-day expectations, prepare for emotional responses, and advise on how to act in social settings. From suggesting the items a pilgrim should carry to micromanaging how and where the pilgrim's attention should be focused, they outline what being a pilgrim entails. As a genre, pilgrim guidebooks always convey the sense that one is "walking in other people's footsteps," even where the physical surroundings bear no trace of a historical community of pilgrims. In framing the pilgrim experience and demarcating it from that of a "normal tourist," the guidebooks prepare for an immersion into a religious past, which is re-imagined and made meaningful as heritage.

After introducing the Norwegian St. Olav Ways and their presentation in the media, we analyze the currently available pilgrim guidebooks, regarding how they inform the pilgrims' expectations and practice throughout the journey. Here, we compare how they present the concept of a St. Olav pilgrimage as distinct from touristic long-distance hiking, and frame the practice of

3 See Council of Europe 2010. 
walking as an immersive heritage encounter. ${ }^{4}$ From considering the journey to instructing the pilgrims for every single day and finally preparing them for the arrival at Nidaros Cathedral, we detail how guidebooks can foster an "interpretive drift" (Luhrmann 1989), a gradual shift in the interpretation of everyday experiences and events. With an analysis of published pilgrim reports from the St. Olav Ways, we conclude that these books frame pilgrimage as cultural heritage, transforming the question of how to be a pilgrim into the question of how to become an heir. The current trend toward a heritagization of religion, we argue, encompasses more than just the use of a new interpretative and administrative framework to approach a religious past. The notion of cultural heritage introduces the role of "heir" as a new identity marker to the wider field of vernacular religion. In this way, the practice of contemporary heritage encounters creates genuinely new religious identities that allow renegotiation of historical traditions in response to contemporary concerns.

The offer presented on official websites of the St. Olav Ways sounds tempting and very contemporary: "Do you want a challenging pilgrimage with historical and cultural bits and pieces on the way?"5 With the historical routes leading to Nidaros Cathedral in Trondheim restored, pilgrimage has recently found its way back into a country with a predominantly Lutheran past and a highly secularized present. As in many other Northern European countries, but on a much larger scale, restored pilgrim routes now reconnect landscapes, Christian sites, and historical monuments to facilitate a new form of active outdoor heritage experience.

The backdrop to this development is a history of former glory and long disruption. Olav Haraldsson was born in 995, became a Norwegian king in 1015, was driven to exile in 1028, and died upon his return in the Battle of Stiklestad in 1030 where he was fighting for the ultimate power over the contested kingdom. Immediately after his death, a venerative movement emerged among his followers to establish his holy martyrdom, spreading rumors of miracles happening near his body. The English missionary bishop Grimketel, who had long served as Olav Haraldsson's spiritual advisor, initiated his beatification in 1031 and the veneration of St. Olav soon became a European phenomenon

4 For the debate on distinctions made between pilgrimage and tourism see the introduction to this issue.

5 See St. Olav Ways, n.d.b. Pilegrimsleden.no is hosted by the NDR. 
(Ekroll 2016: 244). Over time, his burial site at Nidaros Cathedral in Trondheim became the most important pilgrimage destination in Northern Europe. ${ }^{6}$ Churches dedicated or attributed to St. Olav still testify to the popularity he gained all over Northern Europe and beyond. The pilgrimage to the shrine of St. Olav, however, came to a rather abrupt halt when pilgrims faced increasing persecution in the aftermath of the protestant reformation of the unified kingdom of Denmark-Norway in 1537. He is still widely remembered as the king who institutionalized Christianity in Norway by introducing Christian law, although this is historically imprecise. ${ }^{7}$

The first attempt at a modern pilgrimage revival in Norway was undertaken in 1958 by an organized Swedish group starting from Selånger on the east coast of Sweden to arrive at Nidaros Cathedral (Andresen 2005: 112-113). Since 1958, this route has become part of one of the trails of the St. Olav Ways stretching outside Norwegian borders. ${ }^{8}$ The first organized Norwegian group of pilgrims arrived at Nidaros in August 1977 and consisted of 71 persons from the Norwegian Christian Youth Federation (KFUM), the Norwegian branch of the international youth organization YMCA (Vistad 2012: 43). From 1980 onwards, the number of pilgrims arriving at Trondheim increased steadily. In the same year, Nidaros Cathedral established its first pilgrim event, marking the first official involvement in the pilgrimage revival of the Lutheran state church: a walking worship called the St. Olav's Wake (Olavsvaka) on the national memorial day of St. Olav, Olsok, on 29 July. It was not until the 1990s, however, that a larger independent pilgrimage movement emerged in Norway, largely inspired by the Camino de Santiago. The pilgrimage enthusiast Eivind Luthen published the first Norwegian pilgrim book in 1992, describing the historical pilgrimage routes between Oslo and Trondheim (Luthen 1992), and in 1996 he established the Norwegian branch of the Confraternity of St. James (Pilegrimsfelleskapet St. Jakob) "with the aim of spreading knowledge and understanding of pilgrimage nationally and internationally." This gave the initial impulse to a formative project that came to involve local, regional, and national governmental institutions and departments, the Lutheran Church, and independent organizations.

6 The oldest written document describing Olav Haraldsson's merits is Passio Olavi from the late 116os or early 117os. Here the Archbishop Eystein retells the life and death of Olav, the stories of miracles at Olav's grave, and points out Nidaros and Stiklestad as pilgrimage destinations; see Bjerkestrand 2016.

7 E.g., the account on the Nidaros Cathedral websites: https://www.nidarosdomen.no/en/ music-architecture-and-history/olavsarven.

8 Olav allegedly arrived at Selånger when returning from Novgorod in Russia in 1030 to recapture the throne, which explains its relevance as a pilgrim route; St. Olav Ways, n.d.c.

9 See Pilegrimsfelleskapet St. Jakob, Norge/Confraternity of St. James, Norway, n.d. 
Between 1994 and 1997, a historical pilgrim path from Oslo to Trondheim was identified and restored.

When Trondheim celebrated its millennial anniversary in 1997, the first St. Olav Way was officially "re-opened" by Norwegian Crown Prince Haakon Magnus on Olsok. By then, Nidaros Cathedral had already hired its first pilgrimage minister dedicated to serve a growing number of pilgrims. The Ministry of Culture and Church Affairs initiated a national strategy for pilgrimage in 2008 to develop the infrastructure committed to preserving the "Olav-heritage."10 It led to the certification of the St. Olav Ways as a Cultural Route of the Council of Europe in 2010 and the establishment of a national pilgrimage center in Trondheim in 2011 as well as six regional pilgrim centers. Interactions between bottom-up pilgrimage initiatives and top-down strategies and regulations continue to shape the current development of the Norwegian pilgrimage infrastructure (see also Mikaelsson and Selberg 2020). Local stakeholder groups and independent fellowships have suggested new pilgrim paths or contested some established routes in terms of authenticity or touristic value, and regional initiatives have made a significant impact in facilitating a flow of pilgrims. The national organization systematically expands and manages the infrastructure to ensure that governmental directives and ventures are followed.

Currently, nine official routes constitute the growing St. Olav Ways network ranging over 3400 kilometers, the western coastal route being one of the latest additions (see Mikaelsson and Selberg 2020). Currently, the pilgrim path from Selånger is the only non-Norwegian part of the route officially integrated into the St. Olav Ways. ${ }^{11}$ The pilgrim centers have documented growing numbers of registered visitors from all over Europe in the course of the past ten years, recording tens of thousands of annual visitors. Among the nine official routes, the route going from Oslo to Trondheim through Gudbrandsdalen is the longest path and considered the "main road to Nidaros," both historically and with regard to the Dovre Mountains being an iconic spot on the route. ${ }^{12}$ Pilgrims can receive a pilgrim passport and obtain the Olavsbrev (Olav's letter), an official pilgrim certificate, by documenting that they have walked for at least 100 kilometers. However, total numbers are hard to estimate because of the many different starting points, short-term visitors, and the fact that not all visitors make use of the pilgrim passport or certificate. Among registered

10 The relevant documents are accessible at https://pilegrimsleden.no/nasjonalt -pilegrimssenter.

11 See, e.g., the illustrative map at St. Olav Ways, n.d.d. This particular path is advertised as "the northernmost pilgrim path in the world, extending from the Baltic sea to the Atlantic sea, through Sweden to Norway"; see St. Olav Ways, n.d.c. 
pilgrims, most come from Northern and Western Europe, with Norwegians and Germans being the largest groups, followed by visitors from the Netherlands, Switzerland, Sweden, Denmark, Belgium, Austria, and the USA. ${ }^{13}$

Today, potential visitors are welcomed on the official website of the St. Olav Ways with a promise: "Here you may walk ... Here you may dream ... Become revitalized ... Wonder under birdsong ... Arrive at your goal ... A feeling of accomplishment." ${ }^{14}$ Accompanied by pictures of beautiful small paths across mountains and forests, flowing rivers, and a picture of the majestic Nidaros Cathedral that scroll over the screen, the wording evokes ideas of transformative experiences along the routes. Articles on the website describe encounters with the Dovre Mountains, engaging with the history of the Viking king and saint, pilgrim rituals at the historical Nidaros Cathedral, culinary experiences, and making new friends while walking. The official website thoroughly prepares future pilgrims for what they can expect and experience during their walk, while still leaving it up to each individual to arbitrate to which degree the pilgrimage is motivated by religious, cultural, historical, and/or physical elements. ${ }^{15}$ The St. Olav Ways have also received significant attention in international newspapers, magazines, and television documentaries, with many finding the connection between pilgrimage and Norway unexpected and therefore worthy of reporting. ${ }^{16}$ Such features often present Norway as a prime destination for authentic nature experiences, and the St. Olav Ways as a chance for a meaningful exploration of varied landscapes, rustic farms turned into hostels, and a folkloristic storyworld. Contrasted with the more crowded Camino de Santiago, the Norwegian routes appear as an individualistic choice for adventurous travelers. ${ }^{17}$ This media coverage creates quite specific expectations for the route by providing iconic pictures of highland trails and historical buildings, and by highlighting the absence of a liturgical framework. The St. Olav Ways promotional material accentuates that pilgrimage is no longer about the veneration of a Christian saint, but primarily an independent and nonbinding exploration of one's own spirituality. Simply walking the route, the material suggests, will stimulate personal transformation: "Many start out as

13 Recently, electronic "Eco Counters" were installed along the paths to obtain more representative numbers. For the statistics from the different pilgrim centers and the numbers of visitors from different countries, see Jansson/Nasjonalt Pilegrimssenter 2018.

14 See St. Olav Ways, n.d.e.

15 The "many different reasons" for conducting pilgrimages today are also reflected on the official Facebook presence of the St. Olav Ways: https://de-de.facebook.com/pg/Pileg rimsleden/about/ (accessed 28 April, 2020).

16 See, e.g., Enfield 2018; Röther 2019; Smith 2019; Kehoe 2019.

17 See, e.g., Stöckl, n.d. 
athletes and arrive as pilgrims."18 In pilgrim guidebooks, this implicit promise of a transformation is spelled out in detail by instructing the readers on how to become a pilgrim.

\section{Learning to Be a Pilgrim: Guidebooks to the St. Olav Ways}

First things first: You do not have to be a pilgrim in the classical sense to follow the pilgrim trail ... You do not have to be a believer, not a Christian, just enthusiastic about hiking ... And even if there may be hiking trails with a better infrastructure, less tarmac and streets: there is but one historically valuable pilgrim trail, which has been used by so many medieval people at the risk of their lives, where history is present at every corner. ${ }^{19}$

ENGLER 2016

The introduction to a German guidebook frames the experience of walking the St. Olav Ways as an encounter with history. "Walking in other people's footsteps" has become the emblematic aspect of much "new" pilgrimage, combining very practical implications for health, socializing, and well-being with "meta-movement," the combination of mobility "with a degree of reflexivity as to its meaning, form and function" (Coleman and Eade 2004: 18). While Christian faith is no longer a requirement, pilgrim guidebooks still prepare participants for an activity that differs considerably from those undertaken by a tourist or a regular hiker: Being a pilgrim in Norway and following the officially waymarked St. Olav Ways implies walking on routes with a hidden history underneath "tarmac and streets." The fellowship and the meaning of pilgrimage therefore need to be uncovered before they can be embraced.

Guidebooks can play a significant role in shaping the experience of being a pilgrim. In detailing requirements and describing landscapes, historical narratives, and anecdotes from the route, they guide expectations and create models for the identity of a pilgrim. In the following, we compare and analyze how the available guidebooks for the St. Olav Ways frame the pilgrimage. Since 2001, several Norwegian (Berger and Luthen 2005; Thue 2008; Olsen 2013; Brox 2014; Voll and Gilbert 2017), English (Raju 2001), Swedish (Söderlund and Sjöström 2018), and Dutch (Warmerdam 2016, 2017) guidebooks have been published.

18 A quote from Catherine Roncale, Nidaros Pilgrim Centre, used in several features on the Saint Olav Ways, e.g., Bernhard 2015, 2016; Chwaszcza 2019.

19 All translations from German, Norwegian, and Swedish into English are made by the authors unless stated otherwise. 
Matching the numbers of international visitors to the St. Olav Ways, the biggest corpus are German guidebooks (Engler 2016; Lohse 2018; Warmerdam 2018; Weyer and Weyer 2018; Elsner and Elsner 2019a). A fairly recent international format is the publication of companion books adding spiritual, historical, and folkloristic impulses to a guidebook (e.g., Aasmundtveit 2013; Verket 2014; Jensen 2015; Øigarden 2015; Deppe 2018; Elsner and Elsner 2019b; Käll 2019).

While the requirements and restrictions of the handy guidebook format make them well suited for comparison, the books show a significant variety in approaches to their subject. At first glance, all of them mirror the media's focus on authentic nature experiences. Cover illustrations set the scene: almost all of them show pilgrims with heavy backpacks and hiking gear following a small trail through the highland landscapes of the Dovre Mountains. However, paratextual details address different target audiences. Where a German "outdoor" guide marked with "the journey is its own reward" caters to hiking enthusiasts (Engler 2016), other cover pages feature seniors on a group tour (Weyer and Weyer 2018) or emphasize a religious focus: "new: with many spiritual texts" (Lohse 2018). Adapted to their respective target audience, the guidebooks provide practical information while directing attention to a hidden history that becomes the inheritance of every pilgrim.

The following sections detail how the guidebook authors present this history and anchor it in places and landscapes. In the analysis, we follow the functional parts of the guidebooks: those to be read when first considering walking the St. Olav Ways, those addressing practical preparations for the journey, and those that guide the pilgrim through the daily stages up to the ceremonial arrival in Trondheim. Throughout these parts, we identify textual anchoring mechanisms (Davidsen 2016) that connect historical imagination and the "concrete, sensory experience of place" (Reijnders 2011), allowing for a gradual immersion into a reality augmented with elements from a storyworld presented as heritage (Bielo 2018). All parts of the guidebooks can contribute to a process of interpretive drift that we identify in our final section to be a defining feature of the pilgrim experience, as documented in many pilgrim reports.

The Historical Olav and Past Pilgrims: Exploring an Unknown Heritage

By describing a pilgrim route stage by stage, guidebooks provide detailed information on various places, attractions, and activities. Directions to shop for 
food at a mall in Oslo, stroll through a pre-Christian burial ground in Oppdal, and drink from the re-installed St. Olav's well in Trondheim have little in common besides the small waymarks found close to the sites. The short introductory chapters have the crucial task of framing the diverse impulses. What constitutes a pilgrimage in Norway? Within the pilgrim guidebook genre, the popular Camino de Santiago is a natural point of demarcation for introducing the St. Olav Ways. Most introductory chapters make the point that while the St. Olav Ways are inspired by the pilgrimage to Santiago, the experiences will not match it. The guidebooks' presentation of the Norwegian route requires the readers to expand preconceived notions of pilgrimage: less frequented, one has to prepare for moments of solitude rather than "communitas" (e.g., Raju 2001); physically challenging, one has to prepare for exhaustion rather than meditative walking (e.g., Berger and Luthen 2005); with Lutheran churches closed most of the times, one has to discover the spiritual quality of nature (e.g., Lohse 2018; Øigarden 2015, with the title "Nature Guide for Pilgrims. Flowers, Birds and Animals in a Christian Tradition"). The most crucial difference from the Camino de Santiago, however, lies in the ideas that make hiking through Norway a pilgrimage. With the different country and different conditions on the road comes a different saint and a different story.

While space is precious in a guidebook, at least a short chapter addressing the question "Who was Olav?" is necessary for the pilgrim to make sense of the many descriptions of historical sites traditionally connected to Norway's "eternal king" (e.g., Raju 2001: 8; Weyer and Weyer 2018: 9; Voll and Gilbert 2017: 8; Lohse 2018: 19; Engler 2016: 12; Warmerdam 2018: 6; Deppe 2018: 37; Elsner and Elsner 2019a: 26). Norwegian guidebooks need to negotiate how the contemporary revival of pilgrimage relates to the contemporary secular self-image and understanding of national history, while the international guidebooks set an explorative framework in presenting St. Olav as an "unknown" saint. The established legendary narrative of the man, who first went on a Viking raid at twelve years old, was baptized in Rouen, and was considering a pilgrimage to Palestine when he heard a voice telling him to turn back home, follows familiar scripts of conversion and repentance. The subsequent military campaigns in Norway, however, raise the question of how a contemporary pilgrim can relate to the Viking king. Even sober guidebooks challenge the readers: "We go on a pilgrimage to a (since the Reformation no longer visible) grave of a saint whose missionary approach we cannot endorse; a politician, who maybe just used religion to gain autarchy" (Elsner and Elsner 2019a: 29). From this dissonance between past and present values emerges the basic approach shared by all guidebooks to the St. Olav Ways (as well as the official websites) to historicize 
pilgrimage. The reader is asked to relate to St. Olav and the pilgrim route as historical phenomena:

He lived in his own time, and he thought, talked and acted according to the standards and possibilities of his time ... You cannot judge a person of the past by today's standards ... We share the search for our own way and for turning points in our lives. Every person faces the task to find and walk his own way ... Maybe the journey along the way of Saint Olaf, along the stages of his life will open our eyes for the turning points in our own lives.

DEPPE 2O18: 42

Even more than for the Camino de Santiago, where walking was made the hallmark of pilgrimage (Chemin 2015; Bowman and Sepp 2019), the meaning of walking the St. Olav Ways is to be found on the route itself. While Olav is a "difficult Saint," his shrine attracted "thousands and thousands" of pilgrims (Engler 2016: 13) "from all over Europe" (Warmerdam 2018: 6). Thus, it is not the saint but these medieval pilgrim predecessors who are used to give meaning to a contemporary pilgrimage through Norway (Voll and Gilbert 2017: 12). The guidebooks' framing presents a narrative in which pilgrims walk through a remote landscape clustered with "special places" (Engler 2016: 17), "meditative sites" (Elsner and Elsner 2019a: 29), and "cultural heritage sites along the way" (Berger and Luthen 2005: 22), where past and present meet. They seem "charged with spiritual qualities: St. Olav wells, prayer stones, graves, and encampments where once counsel was taken; places where people gathered in times of distress and times of strength" (Lohse 2018:15).

It is not only the documented history of the route itself, but its historicity that makes it stand out, for better or worse: "Because of the way the route, and especially the western option, was conceived, pilgrims in the early 21st century may often feel that they are being led along a route to see where those in the past would have walked, rather than being shown how to be pilgrim themselves" (Raju 2001: 19). Most guidebooks, however, present this hidden history as a unique merit:

You sometimes hike on roads, across fields or private properties - this would not be possible in Germany, but this is not a hiking trail, it is a pilgrim path following a historical route instead of being redirected to the most beautiful landscape. The route lives through its history that is experienced in the churches and rustic pilgrim hostels along the way.

ENGLER 2016: 14 
Even without physical traces of the past,

there is a hidden dimension of reality to the route ... and we are not the first ones to walk along these ways. The stories and fates of our predecessors are inscribed in it, their prayers, desires, and lamentations. Resting an evening after such a walk on a bench where many generations have rested before us will sort things out in life.

LOHSE 2018: 16

The guidebooks prepare the pilgrim for a community with the medieval pilgrims, witnessing and sharing their experiences.

For every stage along the way, the guidebooks provide historical information that evokes medieval times as a reference point. Even hiking through the forest becomes an encounter with history, where one can discover "old" medicinal plants or think about the wishes once uttered at an artesian spring that legend declared a St. Olav's well. Not the campaigns of the Viking king, but the experience of the virtual community of medieval and contemporary pilgrims constitute the narrative of the St. Olav Ways that is unfolded in the guidebooks. History is translated into heritage and the pilgrim into an heir. According to the guidebooks, as a pilgrim, the traveler will reflect on his or her daily experience in the light of the past.

\section{Practicalities: the Pilgrim as an Heir}

The few pages on which the guidebooks narratively frame the pilgrimage by presenting history stand in stark contrast to the practical information that follows. Travel information, climate charts, currency calculators, emergency numbers, as well as information about the regions and the people are common guidebook material. Still, the details are crucial in standardizing the pilgrim experience. Practical information includes places where pilgrims can get their pilgrim passport, and thus "the real journey" begins, and where they receive the stamps for the passport along the route. The limited opening times of Lutheran churches are discussed extensively, not only with regard to spiritual practice, but because they are "well suited for a rest and to refill water, and often come with a visitor toilet" (Engler 2016: 26). The official waymark of the St. Olav Ways - the symbol for a point of interest combined with an Olav's cross (Figure 1) - needs to be introduced in its many variations. Placed as a sticker on lampposts or as a wooden board hanging from trees, hidden behind shrubs or prominently featured on road signs, looking for these waymarks will 


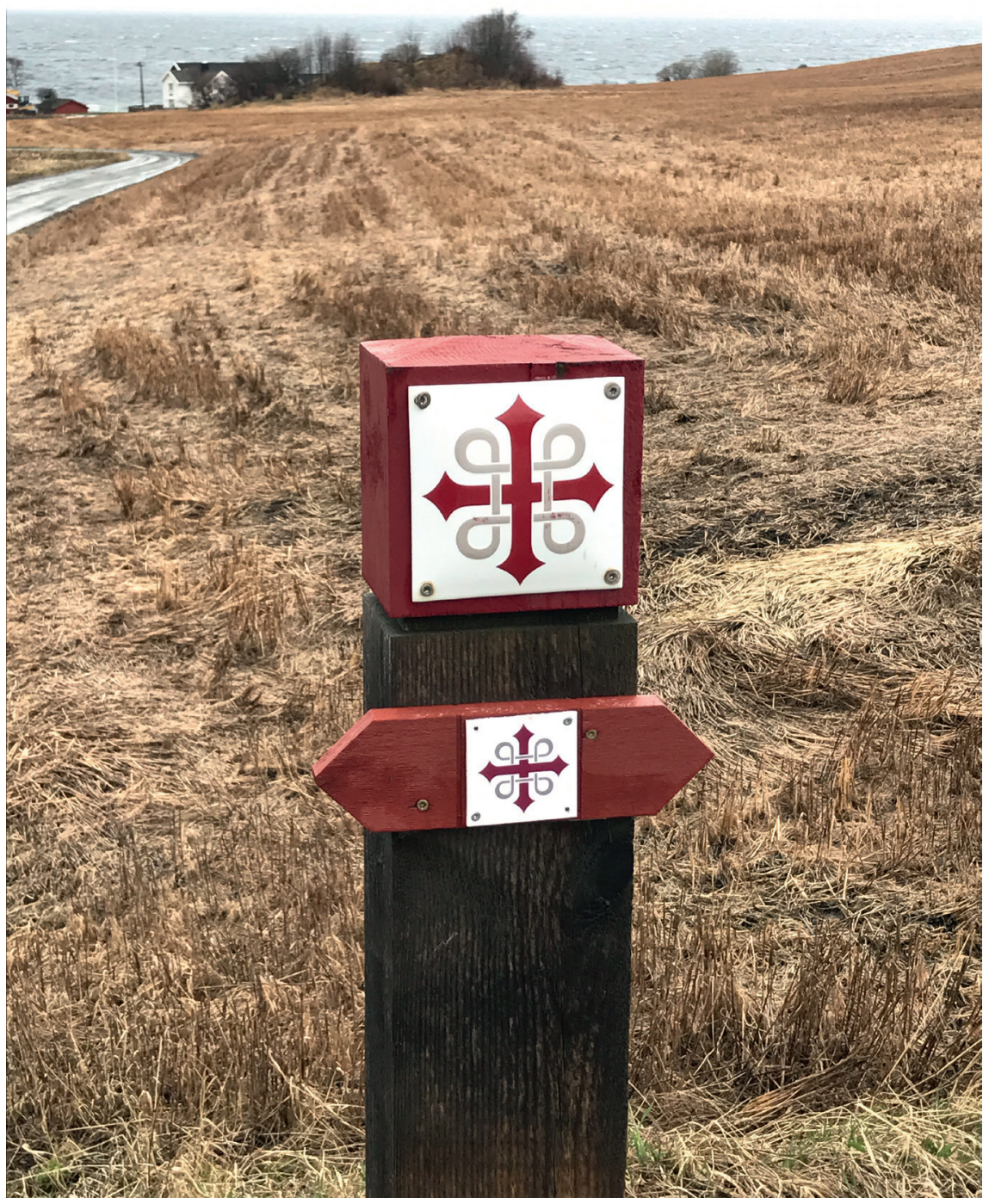

FIGURE 1 St. Olav Ways waymark near Skatval

PHOTO: ANE OHRVIK 
be the most important task of any pilgrim for many days to come (Weyer and Weyer 2018: 18).

Important decisions prior to departure must be made when considering what to bring on a pilgrimage, the guidebooks stress. It determines how easily pilgrims travel, what they can do besides walking, and how they are prepared when their experience does not match their expectations. In general, these preparations for a pilgrimage do not differ from those for an extended hiking trip. But already the suggested packing list can indicate a specific approach to travel, for example by including that a pilgrim would want to reflect on his experiences in writing: "2 sets of underwear ... blister plasters ... pilgrim staff or hiking pole, pilgrim passport and diary and writing tools" (Weyer and Weyer 2018: 22). The aim of limiting weight while still being prepared for shifting climatic conditions or small accidents is relevant for every such journey, but in following a pilgrim guidebook, the process of choosing the right items itself gains a new genealogy. The iconic image of the historical pilgrim in his "medieval 'outdoor gear" becomes a model: "A pilgrim differed from a normal traveler in his attributes ... The symbolism of his bag was important. It was small, because the pilgrim lives modestly, and it was not lockable, because he does not carry valuables and trusts in God's providence" (Warmerdam 2018: 7).

Another emblematic companion is the pilgrim stick, which is a generally recommended object to bring on a pilgrimage: "In medieval times the stick represented the third leg of the pilgrim used as support and to ward off wild animals and burglars. Also today, the stick is a priceless aid to the modern pilgrim" (Voll and Gilbert 2017: 20). To international visitors, Norway's relatively high price levels can become an additional reminder of "walking with intent." In the pilgrim guidebooks, the powdered soup and energy bars that find their way in the backpack become symbols of modesty and restraint. Particularities, such as packing a small stone to be placed at a stone pillar high up in the Dovre Mountains, symbolically leaving one's burdens behind, interlink different stages of the journey.

Guided by chapters with practical information, the preparation sections place the traveler in the role of an heir of medieval pilgrims, and prepare him or her for an immersive heritage encounter. Parts of the equipment gain symbolic connotations, and practical considerations turn into considerations constitutive of a timeless practice of pilgrimage. Addressing the traveler as a participant in a larger, historical imagined community outlined in the initial chapters, the guidebooks frame the pilgrim's perspectives. As the interpreters of their own experiences, the pilgrims "are called upon to live out complex 
blends of cognitive and imaginative response" (Herman 2010: 570). Even where the following main sections of the guidebooks are highly schematic and composed to provide condensed information, they add to the initially presented narrative.

\section{Daily Stages: Walking as an Imaginative Practice}

Pages filled with maps, address lists of accommodations and shops, descriptions detailing where to go, and advice on how to navigate the terrain constitute the main part of every pilgrim guidebook. At a first glance, these very schematic sections may seem of little importance to the study of the dynamics of contemporary pilgrim revivals. Still, the concise format in which the information is presented contains significant extensions to the narrative of the history of pilgrimage, and anchors it in the actual physical surroundings. Pictures, occasional anecdotes, or short textboxes with place-bound histories constantly add to the initial framing. They define the highlights of each given day and allow comparing one's own experience with a previous experience. More subtle is the impact of the implicit scripts provided in the directions themselves. Guidebook accounts are at the same time descriptive and prescriptive. With the historical pilgrim routes crisscrossing towns or leading through rough terrain, the turn-by-turn directions primarily serve to direct the pilgrims' attention. In detailing what to look out for to find the right way, and suggesting where to rest, they create a landscape where the pilgrim belongs, even while still in Oslo:

To your left the church of Frogner is now appearing below the horizon, do not miss the junction leading away from the sidewalk and into the fields (careful: danger of twisting your ankle), up to Frogner church $(11.4 \mathrm{~km})$. Head past the "Santiago de Compostela" sign and the rail station into Frogner. On your left hand is a sandwich bar, a Kiwi supermarket, and a small café. Here they serve good cappuccino for 35 NOK, friendly staff, easy to meet locals.

ENGLER 2016: 55

Out in the wild, the narrative scripts connecting the pilgrim to the path are saturated with descriptions suggestive of affective responses, and aesthetic scripts, narrative elements that provide additional sensory orientation: 
Few waymarks! We note: "before complaining about few waymarks one should think about medieval pilgrims; they had only beaten tracks and no maps or guidebooks." ... We reach the dirt road, pass it, and follow a small path into the woods ... After a small wooden bridge, the ow [Olav's Way] leads up but remains wet. A pleasant walk through the woods. It is silent in the moor ... Only the pilgrim shoes can be heard squelching through muddy puddles. A great atmosphere!

WEYER AND WEYER 2O18: 172-174

The descriptions reflect the embodied and sensory nature of the pilgrims' daily experience to ensure the pilgrim is on track. Where other pilgrims or distinct pilgrim attractions are sparse, the remote route is populated with reminders of an ideal, historical community of pilgrims, manifest at the special places that welcome the pilgrim.

You reach the highest point of the stage at $14.6 \mathrm{~km}$ : Here you are welcomed on $1210 \mathrm{~m}$ by the Olav Way marker Allmannrøysa with a stone pyramid and a box with a pilgrim book. Local tradition in Dovre has it that pilgrims leave a stone as a symbol of a sin, an intercession, a reverence, a thanks, a ... [sic — the ellipses inviting for alternative interpretations]. Wonderful views.

ENGLER 2016: 174

This stone pile is a spiritual place ... We have seen many pilgrims cry and walk away relieved. The view is stunning.

WEYER AND WEYER 2O18: 145

So close to heaven, wishes, prayers, hopes written or painted on stones are said to be fulfilled, and sins to be forgiven or memories literally laid to rest. To pause here for some time is worth it.

ELSNER AND ELSNER 2O19a: 132

The authors allow for a broad range of interpretations when mentioning practices and customs taking place on the pilgrim route. Their descriptions make "stunning views" equally valid to confessional beliefs or therapeutic goals as motivations to engage with a place. The aesthetic and emotional descriptions are not bound to any specific understanding of the meaning of pilgrimage, but still connect the historical and contemporary experience of pilgrimage to the 
materiality of the routes. Being a pilgrim is a learning experience. Step by step, the traveler is directed to discover new traces of historical pilgrims, compare his or her own experience with previous experiences, relate to their feelings, and signal his or her pilgrim status by continuing their traditions.

Gradually, the guidebooks prepare for an immersion into the history of pilgrimage in the form of a heritage encounter. The contemporary pilgrim on his way to Nidaros is addressed as the latest representative in a long line of previous pilgrims. In continuing their role, he or she inherits their acquired right of belonging on the pilgrim route, but also the obligation to carry on the heritage. From reminders "to meticulously check that livestock fence gates are closed only then can the Olav Way be preserved in its current form" (Elsner and Elsner 2019a: 16) to emphasizing that "a pilgrim should always be kind enough" to listen to those telling a story, "even after a long day of walking" (Lohse 2018: 25), the guidebooks convey a sense of responsibility to the route and the pilgrims of the past. Taking on the role of a pilgrim involves exercising cultural and social discipline:

We act with respect for the people we meet on our journey, including those who do not welcome us ... The old scouting rule also applies to pilgrims: "After a stay you only have to leave two things: one is nothing, the other is a thank you to the landowner." ... Do not take hospitality and service attitude as a matter of course, but if anyone still wants to pamper you, receive with joy and gratitude.

BERGER AND LUTHEN 2005: 13

It is not spiritual reflection, but, first and foremost, fulfilling the practical obligations of an heir to the pilgrim tradition that makes a pilgrim a pilgrim.

\section{Arrival at Nidaros: Making Sense of Pilgrimage}

Continue to the Frøset farm, through the forest to Vådån (Votan), a pagan burial ground with many mounds in the forest, and through the residential area Haukåsen to Lian, a hillside with a view on Trondheim. You cannot see the cathedral!

LOHSE 2018: 159

The pilgrim guidebooks direct the pilgrims' attention toward markers of pilgrimage even where the physical surroundings bear no trace of them. In 
selecting what to look for as a waymark, mentioning some attractions but not others, or contextualizing the inevitable blisters and physical exhaustion as an experience shared with medieval predecessors, the reality presented in the guidebooks is highly augmented.

With the focus on the route and the idea of self-consciously walking in the footsteps of medieval pilgrims rather than walking toward a goal, shared by all guidebooks, their description of the arrival in Trondheim and at Nidaros Cathedral ends on a historical note. Just as with the previous historical sites and places, the contemporary pilgrim is presented with the history of Nidaros in the form of a living heritage: "Even though the final resting place of Olav's body is unknown: The significance of Nidaros as the most important Northern European pilgrimage destination from the 11th century until the Reformation in 1537 is currently made alive again" (Engler 2016: 244). Instead of simply describing the route, the guidebooks explain how previous pilgrims have arrived. ${ }^{20}$ Again, descriptions are saturated with aesthetic scripts and emotional descriptions, implying the contemporary pilgrim as a modern heir of medieval religious traditions. The moment the cathedral finally appears in sight is, "as for thousands of pilgrims before us, still a moment to pause!" (Elsner and Elsner 2019a: 181). The embodied meaning-making process of a pilgrimage is not concluded upon arrival: "we are still in the midst of all of it" (Weyer and Weyer 2018: 190). The schedule for arrival is meticulous and standardized, following "good pilgrim custom" (Lohse 2018: 163): Instead of approaching the sanctuary right away, the guidebooks suggest a series of tasks. Walking to the last milestone, checking into accommodation, visiting the pilgrim center to obtain the certificate, and circling the cathedral three times before entering amplifies the feeling of arrival. Only with the pilgrim status officially certified is access to the historical monument granted free of charge, confirming that the pilgrim, indeed, belongs. "Pilgrims do not go on a pilgrimage to experience something new, but to become new (Franz Alt)" (Weyer and Weyer 2018: 192), readers are reminded. The traveler is, again, transformed into a participant in a large, historical community, and a final day exploring the city of Trondheim is suggested to allow for a re-transformation into "the status of an ordinary mortal" (Warmerdam 2018: 168).

20 The official websites of the St. Olav Ways have recently been revised accordingly, and now present Nidaros Cathedral with regard to the "experience to arrive here today," including "rituals of pilgrimage upon arrival," see St. Olav Ways, n.d.f. 

of Experience

The notion of transformation has long been important in both learned Christian pilgrimage discourse (Petsalis-Diomidis 2002) and modern pilgrimage scholarship (Gothóni 1993) and has since become one of the most conspicuous aspects in conceptualizing modern "Caminoized" pilgrimages (Alt et al. 2016). In promotional material, the term often functions as a blank, a semantic vacancy to be filled with meaning by the individual who considers becoming a pilgrim. On the official websites of the St. Olav Ways, for example, pilgrimage has until recently been demarcated from tourism in the promise that "most people will undergo a mental transformation." Accommodating both religious and therapeutic aims and ambitions, the indeterminacy of the concept highlights the individuality of the lasting impact. The guidebooks connect this promise of a transformation to the concrete physical and emotional challenges of the route and the appreciation of moments of hospitality and happiness. Instead of suggesting a singular transformative experience to take place at a specific stage of the pilgrimage, the guidebooks further the notion of a gradual transformation of experience.

To conceptualize the dynamics of an immersive heritage encounter from a cognitive perspective that accounts for the performative and sensory nature of pilgrimage, Tanya Luhrmann's notion of "interpretive drift" could be especially valuable. ${ }^{21}$ Instead of looking for extraordinary experiences to account for the many reports of the efficacy of ritual or prayer, Luhrmann $(1989,2012)$ details the steady engagement with a new form of religious practice as a learning process marked by a subtle shift in "someone's manner of interpreting events." The mechanism triggering this shift is one of cognitive dissonance, a mismatch between expectations and actual experience when following pre-established performative scripts. The effect of a ritual or a prayer may not become evident right away, but the respective settings can guide the interpretative process, where they allow for a broad range of sensory impressions, emotional reactions, and everyday events to be perceived as connected to the act and therefore to gain symbolic meaning. Interpretive drift, thus, is a gradual process, where the lines between just pretending to engage in an act such as speaking to God or channeling energies and perceiving the act as real are fluid. Increasingly immersed into a new interpretative framework, engaging with new practices

21 Luhrmann developed her model to account for "the slow shift to belief" among occult practitioners of magical rituals (1989) and, subsequently, among evangelical Christians hearing the voice of God (2012). 
creates a different perception of reality when practitioners get "progressively more skilled at seeing new patterns in events, seeing new sorts of events as significant, paying attention to new patterns" (Luhrmann 1989: 312). ${ }^{22}$

As with Luhrmann's cases of "slow shift[s] towards belief," conducting a pilgrimage can be understood as a form of "serious play" (see also Bielo 2018: 85-109). Acting "as if" a pilgrim transforms the experience in a way that allows travelers to self-identify as a pilgrim. This interpretive drift become visible in a genre closely aligned to the guidebooks: pilgrim journals. Most guidebooks suggest a diary and a pen to be an essential utensil for a pilgrimage, and retailers such as Amazon now even sell notebooks marked as pilgrim diary for the St. Olav Ways. ${ }^{23}$ The Camino de Santiago has long inspired vast amounts of pilgrim reports and edited journals, and in recent years a significant number have been devoted to the St. Olav Ways as well. In the format of blogs or vlogs, or as printed books in small editions, the genre of the published pilgrim journal is highly conventionalized in structure and its emphasis on practical aspects. In deciding on publication of their journal, many authors want to convey their experiences to friends and interested strangers, while sharing practical and spiritual insights gathered during their journey with (potential) future pilgrims. Accordingly, packing lists, diet plans, efficient laundry ideas, descriptions of the amenities of the accommodations, comments on shortcomings of a specific guidebook, or tips for the difficult sections of the route take much space. These practicalities connect to a documentation of emotional ups and downs and changing reflections on the meaning of pilgrimage.

As striking as the formal homogeneity of the genre is the interpretive pattern visible across the journals. ${ }^{24}$ Initial motivations to embark on a pilgrimage vary considerably, and a survey of published German journals shows widely different initial understandings of the significance of pilgrimage and its expected outcome. Devoted Christians may look for a renewed connection to God (e.g., Brunner 2013; Zahrnt 2018), other travelers walk for therapeutic reasons after periods of change or hardship (e.g., Schildmann 2011; Mirzaian 2014;

22 In cognitive terms, the active immersion into the religious framework cultivates the attention by reconfiguring the ratio between sensory signal and noise; see Johannsen and Kirsch 2019 .

23 See, e.g., http://www.amazon.de/dp/1791325823/ (accessed 30 January 2020).

24 In pilgrim journals, these narrative patterns are, to a certain degree, dependent on the ideal reader. For example, accounts by Norwegian pilgrims differ from those of foreign pilgrims on the St. Olav Ways in that they presume a basic familiarity with Norwegian culture, history, and geography. For the comparison, we therefore chose German printed pilgrim journals as they constitute the largest corpus. We limited the analysis to those available on Amazon in 2019. 
Horncastle 2016), while challenge-seekers want to escape from daily routines (e.g., Detert 2012; Zimmerschied 2018; Gregorius 2018) or simply avoid the scheduled visit of their mother in law (Pichler 2018). ${ }^{25}$ Although following the same route and the same guidebooks, their written accounts align increasingly. The journals are marked by a pattern of recurring dissonance between expectation and experience, followed by attempts to adapt the pilgrim practice to the given circumstances and explore alternative interpretations of the events.

The initial dissonance experience by those walking the St. Olav Ways from Oslo is caused by the stark contrast between the iconic images of remote highland trails used to advertise the St. Olav Ways, and the actual experience of starting the journey in the midst of a busy city. No matter whether the ambition was one of mountain hiking or meditative walking, once the pilgrims' way becomes real - not a remote trail but a pedestrian way between highrises and next to a motorway - many preconceived notions of a pilgrimage through Norway are shattered. The guidebooks mark the initial stages of the St. Olav Ways as emotionally challenging, but the journals show how pilgrims first learn to discern the emotional guidance given in the prosaic turn-by-turn directions. Individual journals highlight a feeling of disorientation when walking with a heavy backpack through fashionable shopping streets, asking for directions only to learn that most locals have never heard of the St. Olav Ways, or even visiting the local branch of the Confraternity of St. James where "the term spirituality was not mentioned once" (Detert 2012: 25). With the pilgrims trying to detect the St. Olav's cross on lampposts and street corners, the guidebooks role in re-directing the pilgrims' attention becomes apparent in the descriptions of the first days on the route. Long stretches of the way leading out of the larger Oslo area are modern residential or industrial areas, and places compatible with ideas of self-reflection and heritage become defining parts of the pilgrim experience, even where they have no traditional connection to pilgrimage. The German War Cemetery of Oslo-Alfaset, for example, turns into the place of a first tranquil rest in several journal accounts, reminding German pilgrims of a difficult national heritage. Leaving the city, all of the journals show how contemporary impressions are increasingly augmented by historical imagination. Increasingly, the route transforms into a series of "special places" described in the guidebooks, each adding "historical bits and pieces" used to realize the story of a virtual community of pilgrims: "What were their thoughts, when they arrived at [this place]?” (Brunner 2013: 50).

25 On the motivations of pilgrims walking the St. Olav Ways, as well as the perceived effects, see Jørgensen et al. 2020. 
At least prior to arriving in Hamar or even Lillehammer, few of the journal authors have encountered other pilgrims. Because of the lack of companions on the road, in the pilgrim journals the communal aspects of pilgrimage are discovered or interpreted as fellowship with past pilgrims. For some, the initial experience of anonymous isolation becomes a necessary step in the transformation into a pilgrim: you have to "become a stranger" first, in order to arrive somewhere (Detert 2012: 10). The most pronounced mismatch between expectation and experience, however, is caused by not being recognized and addressed as a pilgrim. Following a marked pilgrimage way but still being welcomed only as a tourist ("even in the hostels" mentioned in the guidebook; Brunner 2013: 9) manifests the questions that dominates the journals: "am I a pilgrim? ... How do you become a pilgrim? Is there a difference between a pilgrim, a hiker, and a tourist?" (Pichler 2018: 34 ), "do you still walk or are you already on a pilgrimage?" (Zahrnt 2018: 9). These questions are negotiated long into the route: "What differentiates pilgrimage from hiking? We don't have a useful conclusion yet" (Detert 2012: 53 ). Even ascribing the pilgrim status to others can be tricky: "Another German pilgrim admitted to me that she was no pilgrim, and had just used the pilgrim passport to get pilgrim reductions in the hostels along the St. Olav Ways" (Pichler 2018: 209). Instead of relying solely on direct feedback, the virtual community of past and present pilgrims implicit in the very idea of a pilgrim guidebook becomes a partner of dialogue. Early journal entries often co-narrate the guidebooks, highlighting where pieces of practical information matched the situations encountered: the church suggested as a resting spot was indeed closed for visitors on weekdays; the price level at a restaurant seemed indeed over the top; the signpost was indeed hidden by branches and leaves. The small experiences gain crucial relevance in that they seem to match those of prior pilgrims. Several guidebooks indicate hostels, forest shelters, or certain waymarks where a pilgrim would find pilgrim guestbooks, something appreciated by many for the sense of belonging it creates: "By writing something in the book, you become part of the long succession of pilgrims" (Mirzaian 2014: 33). Still, the moment in a journey when the pilgrim status is first explicitly acknowledged ("the innkeeper introduced me to the other guests as a pilgrim," Brunner 2013: 44), becomes a defining achievement and a first turning point in all pilgrim narratives selected for analysis here.

Walking the "historic route" flanked by motorways and shopping centers eventually turns into reflections on the hidden history that now becomes an immersive heritage. The pilgrim journals document this transformation of experience as a guided re-direction of attention to minute detail. Where early journal entries engage with the practicalities involved in being a stranger in an unfamiliar country, later entries can revolve entirely around a friendly smile, 
a good chair, or the guidebook slipping out of the backpack and being handed back by a passing stranger: "Some may call it chance, but I realized ... that God holds a protective hand over his pilgrims" (Brunner 2013: 25). "Pilgrimage ... makes small things big" (Mirzaian 2014: 32). The initially unknown and "difficult" saint ("Olav who?" Pichler 2018: 18; Detert 2012: 8; Zahrnt 2018: 12) is discovered as a presence, with the historical community of pilgrims described in the guidebooks becoming "present, visible, almost palpable" while walking: "The whole time I felt carried, accompanied, and never alone in the open countryside" (Schildmann 2011: 179). In the daily rhythm of "eat, sleep, walk" (Schildmann 2011: 178), sun and rain, historical markers, food, and social interactions are described as gaining symbolic meaning as acts of communication.

In the end, a day that passed without event and just as described in the guidebook can become the moment in which one feels one has arrived on the route, and can fully identify as a pilgrim: "The message can be that simple" (Mirzaian 2014: 19). Notably, the moment where most pilgrim reports describe the feeling of being a pilgrim to be most intense is not the arrival at Nidaros Cathedral. It is the moment where one walks the small highland trails up in the Dovre Mountains depicted on the cover of the pilgrim guidebooks: "It is as if I am walking through a documentary film, with a script written just for me. Only that I can feel and experience everything, in contrast to an uninvolved spectator" (Zimmerschied 2018: 136).

\section{Conclusion: Becoming an Heir}

As both a daily companion and an "objective" voice, pilgrim guidebooks can become a crucial component in entangling "the inner and the outer journey" of a pilgrimage. In contrast to the diverse sources of information consulted by pilgrims prior to their actual journey, they are objects of constant interaction and successive study. They inform day-to-day expectations, micro-manage the pilgrims' attention along the route, and contextualize emotional responses to challenges and accomplishments throughout all stages. At the same time, they are physical manifestations of the journey in its entirety.

The pilgrim guidebooks to the St. Olav Ways outline a gradual transformation of experience to allow the traveler to feel like a pilgrim. While the individual guidebooks demarcate target audiences by indicating a focus on spiritual, cultural, or adventurous activities, none of them identifies a specific mindset or motivation as a requisite of a pilgrimage or imposes a specific interpretation of the traditions or significance of pilgrimage. Instead, they follow the official promotion of the St. Olav Ways in emphasizing historical authenticity. The 
guidebooks create a framework for pilgrims to relate to St. Olav as a historical actor, shaped by his time; to the remote trails and tarmac roads as a historical route, created by the decisions of previous pilgrims; and to pilgrimage not as a confessional but as a historical practice. In giving directions, performative, aesthetic, and emotional indicators connect the historical community of pilgrims to the materiality of the routes. As presented in the guidebooks, the value of the St. Olav Ways as a pilgrim route lies in its historicity. Whether they address Norwegians or foreign pilgrims, the guidebooks as a genre emphasizes pilgrimage as a transnational tradition of long-distance traveling and cultural experiences. Framed as European cultural heritage, pilgrimage becomes an immersive heritage encounter. Being a contemporary pilgrim, therefore, means continuing traditions, obligations, and the experience of pilgrimage, independent of their interpretation and even of their valuation. The pilgrim has to take on the role of an heir. In the pilgrim journals, we found that relating to the pilgrim past as an inheritance is central for the pilgrims to create a sense of belonging and give meaning to situations that did not match their expectations. In taking a heritagized perspective and embodying the pilgrim as an heir, the routes transform into "places of imagination," "material reference points" (Reijnders 2011: 19) of the historical narrative presented in the guidebooks.

As an example of the dynamics triggered by processes of heritagization of religion, the analysis of the pilgrim guidebooks to the St. Olav Ways indicates that heritagization needs to be understood as a significant reconfiguration within the religious field. Similar to the dynamics encoded in the notion of a scientification of religion, heritagization of religion is a process in which religious traditions, practices, imaginations, and infrastructures are dismantled and reassembled in a new framework. As was the case with the scientific paradigm of the late 19th century, when for example occult movements extracted selected practices from diverse religious traditions to combine them in systems of "occult science," the current heritage paradigm invites people to reengage in selected practices from religious history, made meaningful not by a doctrinal argument, but by the experiences of past practitioners. Such dynamics lead to new claims of ownership (e.g., by governmental agencies or cultural associations rather than religious institutions), new prerogatives of interpretation (such as the now common claim that one cannot understand pilgrimage other than by walking, as it is about shared experiences rather than matters of faith), and new demarcations of religion(s). Processes of heritagization of a religious past are religiously productive. Administrative infrastructures (such as the cultural heritage sector) and professional actors (such as historians or travel guides) now increasingly provide new arenas where religious practices can be embraced based on their perceived historicity. Crucially, new forms of 
religious self-understandings and religiosity become possible, implying new criteria for selecting, arranging, and legitimizing pre-established practices to appear as self-evident. Processes of heritagization of religion imply the role of an heir, who, as a new actor in the religious field, reconfigures what we study when we study religion.

\section{Acknowledgments}

The article is based on research funded by the EEA Financial Mechanism 20142021 Baltic Research Program in Estonia as part of the Norwegian work package of the project Re-storied Sites and Routes as Inclusive Spaces and Places: Shared Imaginations and Multi-layered Heritage (EMP 340$)$.

We thank Marion Bowman for substantial input on the fundamental ideas underlying this study, for the continuous vibrant discussions on pilgrimage, and detailed feedback on the draft versions of this article.

\section{References}

Aasmundtveit, Anne Kristin. 2013. Alle mine veier: En pilegrims vandringer. Oslo: Luther forlag.

Alt, Franz, Bernd Lohse, and Helfried Weyer. 2016. Aufbruch zur Achtsamkeit: Wie Pilgern unser Leben verändert. Freiburg im Breisgau: Herder.

Andresen, Knut. 2005. Olsok i Nidaros Domkirke. Trondheim: Tapir Akademisk forlag. Berger, Tormod, and Eivind Luthen. 2005. Pilegrimsguiden: Hamar - Nidaros. Stockholm: Verbum forlag.

Bernhard, Bettina. 2015. "Pilgern mit Troll-Zoll." Stuttgarter Nachrichten, 22 August. URL: https://www.stuttgarter-nachrichten.de/inhalt.norwegen-pilgern-mit-troll -zoll.7cbgecf5-a3b7-403c-931a-fine57c1fb16.html (accessed 30 January 2020).

Bernhard, Bettina. 2016. "Auf dem Olavsweg wird Tribut an den Troll-König fällig." Die Welt, 4 November. URL: https://www.welt.de/reise/nah/article15911o 625/Auf-dem-Olavsweg-wird-Tribut-an-den-Troll-Koenig-faellig.html (accessed 30 January 2020).

Bielo, James S. 2018. Ark Encounter: The Making of a Creationist Theme Park. New York: New York University Press.

Bjerkestrand, Steinar. 2016. "St. Olav på 10oo-tallet." In Øystein Ekroll (ed.), Helgenkongen St. Olav $i$ kunsten, Trondheim: Museumsforlaget, 7-26.

Blake, Janet. 20oo. "On Defining the Cultural Heritage." International \& Comparative Law Quarterly 49(1): 61-85. 
Bowman, Marion, and Tiina Sepp. 2019. "Caminoisation and Cathedrals: Replication, the Heritagisation of Religion, and the Spiritualisation of Heritage." Religion 49(1): 74-98.

Brox, Karl H. 2014. Over Dovrefjell: Langs pilegrimsled og kongevei. Trondheim: Museumsforlaget.

Brunner, Sebastian. 2013. 24 Tage am Olavsweg in Norwegen: Eine Pilgerreise von Oslo nach Trondheim. Norderstedt: Books on Demand.

Chemin, Eduardo. 2015. "The Return of the Pilgrim and the Seductions of the Way: The Road to Santiago as a Liminal Space." In Michael A. Di Giovine and David Picard (eds.), The Seductions of Pilgrimage: Sacred Journeys Afar and Astray in the Western Religious Tradition, London: Routledge, 211-232.

Chwaszcza, Joachim. 2019. "Pilgern auf Norwegisch." Ärztliches Journal, July. U R L: http:// www.aerztliches-journal.de/reise/reportagen/norwegen/reisereportagen/pilgern -auf-norwegisch/6d9394b8a36boo3off62f85e91e6baga/ (accessed 30 January 2020).

Coleman, Simon, and John Eade. 2004. Reframing Pilgrimage: Cultures in Motion. London: Routledge.

Council of Europe. 2010. "Route of Saint Olav Ways." URL: https://www.coe.int/en/ web/cultural-routes/the-route-of-saint-olav-ways (accessed 30 January 2020).

Davidsen, Markus A. 2016. "The Religious Affordance of Fiction: A Semiotic Approach.” Religion 46(4): 521-549.

Deppe, Olaf. 2018. Nach Nidaros ... Geschichten und Impulse zur Pilgerreise auf den Olavswegen. Paderborn: Bonifatius.

Detert, Lothar. 2012. Olavsweg: Eine Pilgerreise durch Norwegen. Norderstedt: Edition rastlos-media.

Ekroll, Øystein. 2016. “Olavsrelikviar — myter og fakta." In Øystein Ekroll (ed.), Helgenkongen St. Olav i kunsten, Trondheim: Museumsforlaget, 243-296.

Elsner, Susanne, and Walter Elsner. 2019a. Olavsweg (Rother Wanderführer). Munich: Bergverlag Rother.

Elsner, Susanne, and Walter Elsner. 2019b. Impulse zum Pilgern in Norwegen: Spirituell unterwegs auf dem Olavsweg von Oslo nach Trondheim. Norderstedt: Books on Demand.

Enfield, Lizzie. 2018. "Sacred Steps: Walking Norway's St Olav Ways." Financial Times, 12 October. URL: https://www.ft.com/content/435aorf2-cd2e-11e8-8dob -a6539b949662 (accessed 28 April 2020).

Engler, Hanna. 2016. Norwegen: Olavsweg (Outdoor: Der Weg ist das Ziel). Welver: Conrad Stein Verlag.

Eriksen, Anne. 2014. From Antiquities to Heritage: Transformations of Cultural Memory. New York: Berghahn.

Gothóni, René. 1993. "Pilgrimage = Transformation Journey." Scripta Instituti Denneriani Aboensis 15 (The Problem of Ritual): 101-115. 
Gregorius, Harald F. 2018. Danke, Olav! Einsichten und Begegnungen auf einem Pilgerweg in Norwegen. Saarbrücken: Geistkirch.

Harrison, Rodney. 2013. Heritage: Critical Approaches. London: Routledge.

Herman, David. 2010. "Storyworld." In David Herman, Manfred Jahn, and Marie-Laure Ryan (eds.), Routledge Encyclopedia of Narrative Theory, London: Routledge, 569-570.

Horncastle, Mona. 2016. 420 km til Nidaros: Achtsam pilgern zu mir selbst - Auf dem Olavsweg nach Trondheim. n.p.: Horncastle.

Jansson, Mattias/Nasjonalt Pilegrimssenter. 2018. "Statistikk Gudbrandsdalsleden og St. Olavsleden 2017." URL: https://pilegrimsleden.no/assets/images/Statistikk -Pilegrimsleden.-St.Olavsvegene-til-Trondheim-2017.-Gudbrandsdalsleden-og -St.Olavsleden.pdf (accessed 27 January 2020).

Jensen, Roger. 2015. Pilegrim: Lengsel, vandring, tenkning — før og nå. Oslo: Novus forlag.

Johannsen, Dirk, and Anja Kirsch. 2019. "Narrative Strategies." In Anne Koch and Katharina Wilkens (eds.), The Bloomsbury Handbook of Cultural and Cognitive Aesthetics of Religion, London: Bloomsbury, 143-154.

Jørgensen, Nanna Natalia, John Eade, Tor-Johan Ekeland, and Catherine A. N. Lorentzen. 202O. "The Processes, Effects and Therapeutics of Pilgrimage Walking the St. Olav Way." International Journal of Religious Tourism and Pilgrimage 8(1): 33-50.

Käll, Ulla. 2019. Pilegrim: Langs veien og ved kjøkkenbordet. Stockholm: Verbum.

Kehoe, Jacqueline. 2019. "The World's Northernmost Pilgrimage Route Is in Norway and Almost No One's Heard of It." Afar, 19 January. URL: https://www.afar.com/ magazine/the-worlds-northernmost-pilgrimage-route-is-in-norway-and-almost -no-ones-heard (accessed 28 April 2020).

Kidd, Jenny. 2018. “Immersive' Heritage Encounters." The Museum Review 3(1). URL: http://articles.themuseumreview.org/tmr_vol3no1_kidd (accessed 13 May 2020).

Lohse, Bernd. 2018. Der Olavsweg: Pilgerführer von Hamar nach Trondheim. Kiel: Lutherische Verlagsgesellschaft.

Luhrmann, Tanya. 1989. Persuasions of the Witch's Craft: Ritual Magic in Contemporary England. Cambridge, MA: Harvard University Press.

Luhrmann, Tanya. 2012. When God Talks Back: Understanding the American Evangelical Relationship with God. New York: Vintage Books.

Luthen, Eivind. 1992. I pilegrimenes fotspor til Nidaros. Oslo: Cappelen.

Meskell, Lynn (ed.). 2015. Global Heritage. Malden, MA: Wiley Blackwell.

Meyer, Birgit, and Marleen de Witte. 2013. "Heritage and the Sacred: Introduction." Material Religion 9(3): 274-28o.

Mikaelsson, Lisbeth, and Torunn Selberg. 2020. "Caminoization at Sea: The Fjord Pilgrim Route in Norway." Numen 67 $\left(5^{-6)}: 537-556\right.$. 
Mirzaian, Susanna. 2014. Im Laufen leben lernen: Auf dem Olavsweg von Hamar nach Trondheim. Hamburg: Tredition.

Nidaros Cathedral. n.d. "St. Olav." uRL: https://www.nidarosdomen.no/en/music -architecture-and-history/olavsarven (accessed 30 January 2020).

Øigarden, Trond. 2015. Naturguide for pilegrimer: Blomster fugler og dyr i kristen tradisjon. Oslo: Novus forlag.

Olsen, Harald. 2013. Havets pilegrimer. Stockholm: Verbum.

Petsalis-Diomidis, Alexia. 2002. "Narratives of Transformation: Pilgrimage Patterns and Authorial Self-Presentation in Three Pilgrimage Texts." Journeys: The International Journal of Travel and Travel Writing 3(1): 84-109.

Pichler, Bernhard. 2018. Der Olavsweg: Pilgern in Norwegen. Purbach am Neusiedler See: Bernhard Pichler.

Pilegrimsfelleskapet St. Jakob, Norge/Confraternity of St. James, Norway. n.d. URL: http://www.pilegrim.no/page.php?id=1090320411 (accessed 11 February 2020).

Raju, Alison. 2001. The Pilgrim Road to Nidaros: St. Olav's Way - Oslo to Trondheim. Kendal: Cicerone.

Reijnders, Stijn. 2011. Places of the Imagination: Media, Tourism, Culture. Burlington, VT: Ashgate.

Röther, Christian. 2019. "St. Olavsweg': Pilgern auf Norwegisch." Deutschlandfunk, 1 October. URL: https://www.deutschlandfunk.de/st-olavsweg-pilgern-auf-norwegisch .886.de.html?dram:article_id=46ooo6; https://www.bbc.com/news/world-europe -19049130 (accessed 28 April 2020).

Rots, Aike P., and Mark Teeuwen (eds.). 2020. Sacred Heritage in Japan. Abingdon: Routledge.

Salemink, Oscar. 2016. "Described, Inscribed, Written Off: Heritagisation as (Dis)connection." In Philip Taylor (ed.), Connected \& Disconnected in Viet Nam: Remaking Social Relations in a Post-socialist Nation, Acton: ANU Press, 311-346.

Schildmann, Michael. 2011. Pilgern auf dem Olavsweg: Ein Pilgertagebuch. Oldenburg: Edition Lichtblick.

Smith, Phoebe. 2019. "Nordic Walking: A Pilgrims' Route From Oslo to Trondheim." The Guardian, 23 March. URL: https://www.theguardian.com/travel/2019/mar/23/ norway-camino-path-pilgrims-hike-walk-oslo-trondheim-st-olavs-olafs (accessed 28 April 2020).

Söderlund, Staffan, and Marie Sjöström. 2018. St Olavsleden: pilgrimsfärd från hav till hav, en guide. Gemla: Vildmarksbiblioteket.

St. Olav Ways. n.d.a. "National Pilgrim Center." URL: https://pilegrimsleden.no/ nasjonalt-pilegrimssenter (accessed 20 January 2020).

St. Olav Ways. n.d.b. “Kløfta — Jessheim.” uRL: https://pilegrimsleden.no/en/tours/ klofta-jessheim (accessed 30 January 2020). 
St. Olav Ways. n.d.c. "St. Olavsleden." URL: https://pilegrimsleden.no/en/trails/st -olavsleden (accessed 7 February 2020).

St. Olav Ways. n.d.d. "Maps." URL: https://pilegrimsleden.no/en/kart (accessed 11 February 2020).

St. Olav Ways. n.d.e. "Gudbrandsdalsleden." UR L: https://pilegrimsleden.no/en/trails/ gudbrandsdalsleden-1 (accessed 11 February 2020).

St. Olav Ways. n.d.f. Homepage. URL: https://pilegrimsleden.no/en/ (accessed 11 February 2020).

St. Olav Ways. n.d.g. "Nidaros Cathedral.” URL: https://pilegrimsleden.no/en/articles/ nidarosdomen (accessed 30 January 2020 ).

Stöckl, Johanna. n.d. "Warum das Pilgern auf dem Olavsweg ein Erlebnis ist." GEO. URL: https://www.geo.de/reisen/reiseziele/17224-rtkl-norwegen-warum-das-pilgern-auf -dem-olavsweg-ein-erlebnis-ist (accessed 28 April 2020).

Thue, Stein. 2008. Pilegrimsleden inn mot Trondheim. Trondheim: Tapir Akademisk forlag.

Tolia-Kelly, Divya P., Emma Waterton, and Steve Watson (eds.). 2017. Heritage, Affect and Emotion: Politics, Practices and Infrastructures. (Critical Studies in Heritage, Emotion and Affect). Abingdon: Routledge.

UNESCO. n.d. "Heritage of Religious Interest. UNESCO Initiative on Heritage of Religious Interest." URL: https://whc.unesco.org/en/religious-sacred-heritage/ (accessed 20 January 2020).

Verket, Lars. 2014. Padlepilegrim. n.p.: Lars Verket.

Vistad, Guro Kristiane Berge. 2012. "Den norske pilegrimsrenessansen: En analyse av tilretteleggere, interessenter og prosesser.” M.A. dissertation, Norwegian University of Science and Technology.

Voll, Bjørn Ivar, and Ellen Rykkja Gilbert. 2017. Pilegrimsleden: Fra Oslo til Trondheim En praktisk guide til vandringen. Oslo: Gilbert \& Voll.

Warmerdam, Ria. 2016. Het Olavspad: Gudbrandsdalsleden Noorwegen van Oslo naar Trondheim. Amsterdam: Op Vrije Voeten.

Warmerdam, Ria. 2017. St. Olavspad Zweden: van Selånger naar Trondheim Wandelsgids bij de pelgrimsroute naar Nidaros. Amsterdam: Op Vrije Voeten.

Warmerdam, Ria. 2018. St. Olavsweg: Wanderführer für den Pilgerweg nach Nidaros. Amsterdam: Op Vrije Voeten.

Weyer, Helfried, and Renate Weyer. 2018. Olavsweg. Pilgern in Norwegen (Terra PilgerReiseführer). 2nd ed. Steinfurt: Tecklenborg.

Zahrnt, Thomas. 2018. Gen Norden: Pilgern auf dem Olavsweg von Hamar nach Trondheim. Kiel: Lutherische Verlagsgesellschaft.

Zimmerschied, Jürgen W. 2018. Und ich ging meinen Weg. Olavsweg Norwegen Tagebuch einer außergewöhnlichen Wanderung. n.p.: n.p. 